\title{
The Impact of Project-Based Learning on Students' Cultural Awareness
}

\author{
Akharraz Mohamad \\ University of Ibn Zohr \\ moahamad.akharraz@edu.uiz.ac.ma
}

DOI: $\underline{\text { http://doi.org/ 10.36892/ijlls.v3i2.601 }}$

\begin{tabular}{ll}
$\begin{array}{l}\text { Received: } \\
\text { 19/04/2021 }\end{array}$ & Abstract \\
Accepted: & project-based learning (PjBL) in culture teaching/learning in second and foreign \\
$29 / 05 / 2021$ & language education, no study known to the investigator has empirically measured \\
& the effect of PjBL together with the cultural framework of the 3Ps (products, \\
& practices, and perspectives) in the teaching of culture in an EFL context. This \\
\hline Keywords: & study aimed to measure the effect of PjBL on students' awareness of the English \\
culture teaching, & cultures. Two intact groups at a Moroccan public school were randomly assigned \\
cultural products, & to control and treatment groups. A cultural awareness test was utilized to \\
cultural practices, & measure students cultural awareness levels before and after a 24-week \\
cultural & treatment. The independent sample t-tests indicated that the PjBL group \\
perspectives, & substantially outperformed the control group in cultural awareness. While the \\
project-based & study concluded that PjBL is a useful tool for incorporating cultures in the EFL \\
learning, project & classes, its proper implementation entails a redistribution of power in the \\
work, seven-step & language classroom and a radical change in the culture of assessment. \\
process. &
\end{tabular}

\section{INTRODUCTION}

Although project-based learning is not a new approach to learning (Pecore, 2015; Thomas, 2000), it was introduced into language education during the 1980s to implement student-centered teaching principles (Hedge, 1993). Since then, a growing number of researchers have been promoting it as an effective means to content and language learning (Alan \& Stoller, 2005; Mohan \& Beckett, 2003; Stoller, 2006). However, while an emerging body of empirical research has documented its effectiveness in language teaching (e.g., vocabulary (Migdad, 2016; Mohamadi, 2018; Reisi \& Saniei, 2016; Shafaei \& Rahim, 2015), language skills (Chu et al., 2011; Fragoulis, 2009; Nassir, 2014; Newprasit \& Seepho, 2015; Purti et al., 2017; Simpson, 2011; Yaman, 2014), learner's autonomy (Imtiaz \& Asif, 2012; Yuliani \& Lengkanawati, 2017), leadership skill (Migdad, 2016), positive attitudes (e.g., Bas \& Beylan, 2010; Bas, 2011; Chu et al., 2011; Hsu, 2014; Nassir, 2014)), its effectiveness in the context of culture teaching is still not widely understood. Given the deficiency in the research on $\mathrm{PjBL}$ in the area of culture teaching, the primary purpose of this study is to empirically investigate the effect of the PjBL approach (Stoller's seven-step process) together with the cultural framework of the 3Ps on students' cultural awareness of the English cultures in the Moroccan secondary EFL classes. By investigating the effect of the PjBL approach in culture teaching in the Moroccan EFL context and other similar contexts, the results of this study might resolve a set of challenges faced by EFL instructors whenever the issue of culture is raised. Furthermore, the teaching practitioners, curriculum and course designers, material developers, and those involved with assessment might also be encouraged to use the $\mathrm{PjBL}$ approach to promote language and culture learning.

\section{LITERATURE REVIEW}




\subsection{Project-Based Learning}

Insights from studies and books investigating the scope of PjBL have shown that a single agreed-upon definition does not exist. PjBL has been treated under various concepts that some scholars sometimes consider complementary and interchangeable with no difference in meaning. The scope of PjBL is captured by several terms given to classroom approaches that integrate projects (Beckett, 2002; Stoller, 2006). The two authors cited various terms widely used in general education and L2 education literature. Among the names mentioned are Experiential and negotiated language learning (e.g., Eyring, 2001; Legutke \& Thomas, 1991; Padgett, 1994); Investigative research ( e.g., Kenny, 1993); Problem-based Learning ( e.g., Savoie \& Hughes, 1994; Wood \& head, 2004); Project Approach or Project-based Approach ( e.g., Diffily, 1996; Ho, 2003; Levis \& Levis, 2003; Papandreou, 1994); Project Work ( e.g., Fried-Booth, 1986, 2002; Haines, 1989; Henry, 1994; Lee et al., 1999; Shoring, 1990; Phillips, Burwood, \& Dundford, 1999); Project Method (Kilpatrick, 1926), Project Oriented Approach (Carter \& Thomas, 1986). These labels disclose plenty of features commonly associated with PjBL: experiential learning, negotiated meaning and experience, research and inquiry, problem-solving, and projects (Stoller, 2006).

Although $\mathrm{PjBL}$ is not uniformly defined in the context of language learning, most definitions are complementary and display common features. For example, Beckett (2002) defines $\mathrm{PjBL}$ as "a long-term activity that involves a variety of individual and cooperative tasks such as developing a research plan and questions, and implementing the plan through empirical or document research that includes collecting, and reporting data orally and/or in writing" (p.54). Similarly, according to Fried-Booth (2002), "project work is a studentcentered and driven by the need to create an end-product. However, it is the route to achieving this end-product that brings opportunities for students to develop their confidence and independence and to work together in a real-world environment" (p.6). The Longman dictionary of language teaching and applied linguistics defines PW as an activity that centers around completing a task and usually requires an extended amount of independent work either by an individual student or by a group of students. Much of this work takes place outside the classroom. PW often involves three stages: classroom planning, carrying out the project, and reviewing and monitoring (Richards \& Schmidt, 2010, p. 3). Morgan (1983) defines PjBL as "an activity in which students develop an understanding of a topic or issue through some kind of involvement in an actual (or simulated) real-life problem or issue and in which they have some degree of responsibility in designing their learning activities" (p.1).

Implicit from the abovementioned definitions is that there has been no uniformly agreed-upon model of PjBL. Two main reasons have made it hard to articulate one single definition. First, the multi-disciplinary nature of the term has made the concept of project hard to clarify (Pecore, 2015; Welsh, 2006). Second, the versatility of PjBL considers the numerous ways in which the term can be put into practice (Stoller, 2006). According to Thomas (2000), the absence of a uniformly-greed upon definition has resulted in an array of $\mathrm{PjBL}$ research and development activities.

However, an examination of the above-mentioned memorable definitions in terms of content reveals that the definitions are complementary, as they exhibit some shared features. These features perfectly align with both the underlying principles of constructivism and the impetus for project method development away from traditional teaching. Unlike traditional classrooms, where students receive information passively, PjBL is a teaching model that stresses the active construction of knowledge through a set of activities under the umbrella of projects. For example, students develop a research plan, collect data, interview, report the finding, and evaluate language learning and content knowledge. The word act or action on the part of learners is the most significant PW contribution (Stevenson, 1921). Another common feature of $\mathrm{PjBL}$ is a student-centered activity. Unlike the usual classroom practices 
of short, isolated, and teacher-based lessons, students in the PjBL classrooms have the opportunity to enhance their understanding and knowledge while exploring the subject matter content. In so doing, students develop their reasoning away from passive reception of information, assume the responsibility of their tangible outcomes, and develop their knowledge ownership. Thus, students become producers and constructors of knowledge rather than passive receivers. Another feature embedded in the definitions is that the PjBL tasks are long-term activities usually done collectively or individually outside the classroom. While traditional teaching and learning were restricted to four classroom walls, the $\mathrm{PjBL}$ approach originally came to bridge the yawning gap between what is taught in the classroom and the real-world. Central to the PjBL approach is the assumption that learning is effective only when students relate theory to practice (Harmer \& Stokes, 2014).

\subsection{Insights from Literature underpinning PjBL}

\subsubsection{Learner autonomy}

One of the significant factors that have brought $\mathrm{PjBL}$ to the forefront is the growing interest in learner autonomy. Fostering learner autonomy has been deemed an impetus for the introduction of PjBL to the context of language education (Beckett, 2002). As the concept of autonomy has been gaining in popularity, it has acquired many shades of meaning to the extent that sometimes it causes confusion as to what learner autonomy might entail. Gardner and Miller (1999) stated that "the concept of autonomous learning stemmed from debates about the development of life-long learning skills and the development of independent thinkers, both of which originated in the 1960s" (p. 6). The concept became popular in the 1970s when Henri Holec introduced it to second language pedagogy to discuss alternatives to the established language teaching tradition in the context of adult language learning (Aoki, 1999; Lennon, 2012). The call for learner autonomy development was essentially emanated from the assumption that learning in traditional classrooms was highly teacher-controlled and teacher-centered in methods. Learning as such does not give enough room for students to build up their life-long learning skills, critical thinking skills, learner learning skills, etc. Little (1999) argues that learning will be more efficient when learners are critically aware of goals and methods. Through the development of such critical awareness, learners are empowered to transcend the limitations of their learning environment (p. 11).

There is not a single definition of learner autonomy. Despite their diversity, the existing definitions have much in common. Holec (1881) defines autonomy as "the ability to take charge of one's own learning" (as cited in Benson, 2006, p. 22). More explicitly, Aoki (1999) sees learner autonomy as a capacity (ability) to take control of one's learning in the service of one's perceived needs and aspirations. Learner autonomy as a capacity refers to the domain-specific knowledge and skills necessary (1) to make choices concerning what, why, and how to learn, (2) to implement the plan, and (3) to evaluate the outcome of learning (p. 144). The question is, how can instructors push their learners to take charge of their learning and "chart their own pathways to success?" (Brown, 2000, p. 130).

Strategies and techniques to bolster learner autonomy in the language classroom are documented in a substantial body of research. While these suggestions vary, they have much in common. One of the things they have in common is a call for a re-definition of both students' and teachers' roles in the learning process. This role-restructuring has been deemed a pre-requisite to the implementation of learning autonomy. If learner autonomy is broadly viewed as learners' capacity (ability) to take charge of their learning, these learners ought to be allowed enough freedom to voice out their learning needs, set their own goals, and be able to make decisions. Benson (2006) stated that "many advocates of autonomy argue that some degree of freedom in learning is required if learners are to develop their autonomy" (p. 22). However, "claims have been made that autonomy should not necessarily imply total independence" (Aoki, 1999, p. 143). To put it differently, teachers should provide sufficient 
support that paves the way for promoting learners' autonomy as excessive support will be inadequate support.

PjBL, as the most learner-centered approach (Eyring, 1997; Krauss \& Boss, 2013), can be a pertinent teaching approach to promote learner autonomy in the language classroom. Its strength lies in its underlying principles and features. Of the underlying tenets of PW is the students' choice of the topic. Students are allowed to design and plan their projects in the PW classroom under their tutor's guidance. Students also decide on the tangible outcome and the way they want to share it with an audience. Krauss and Boss (2013) pointed out that in $\mathrm{PjBL}$, "students have a degree of control over what they learn, how they learn, and how they express their learning" (p. 7). During the project process, the instructor takes on the role of a facilitator and offers assistance only if it is necessary. Fried-Booth (2002) stated that "project work pushed forward the boundaries by bringing students into direct contact with authentic language and learning experiences not usually available within the four walls of ELT classroom using textbooks" (p. 6). She continued that "project work offered learners an opportunity to take a certain responsibility for their own learning, encouraging them to set their own objectives in terms of what they wanted and needed to learn" (p.6).

\subsubsection{Theory of motivation}

Research on motivation has shown that motivation is a necessary precondition for students' involvement in learning activities (e.g., Ames, 1990, 1992; Malone \& Lepper, 1987). Ames (1990) quoted Terrell H. Bell that "there are three things to remember about education. The first is motivation. The second is motivation. The third is motivation" ( $p$. 409). "Student's motivation has, for some time, been described as one of the major problems in education (....) Motivation is important because it contributes to achievement, but it is also important itself as an outcome" (Ames, 1990, p. 410). Because motivation is the catalyst for human learning, substantial research has been written about its principles and instructors' strategies to promote it in their classrooms.

Although various theories of motivation (Behavioral, Cognitive, and Constructivist) differ in perspectives, they still agree that the concept of needs remains the fundamental driving force (Brown, 2000, pp. 168-169) that can undermine or facilitate students' development of motivation to learn. Besides needs, other motivational factors play a significant role in encouraging learners to show interest in a learning task. Festo and McClure (2005) claimed that learners are motivated when:

- they believe their actions will result in completing challenging tasks,

- the activities appeal to their personal needs, motives, and interests,

- they have specific near-term goals that they believe are important, and

- the lessons incorporate appropriate levels of variety, choice, and surprise (p. 155).

Similarly, Stoller (2006) asserted that many theories suggested that humans are motivated when these conditions exist: individuals need to (a) feel competent, (b) be granted sufficient autonomy, (c) have the opportunity to set worthwhile goals, (d) receive feedback, and (c) be positively affirmed by others (p. 29).

Likewise, Ames $(1990,1992)$ argued that the development of students' motivation to learn is hugely dependent on whether classroom learning is structured to bolster mastery goal and performance goal-orientations. Both orientations are determined by students' selfconcept of ability or self-efficacy (self-worth) as it is a significant mediator of cognitive, affective, and behavioral variables. Students with a low self-concept of ability are less likely to choose challenging tasks or use self-regulatory strategies because they are concerned more with their ability, self-worth, and normative performance. Therefore, their motivation lasts for a short term and can vanish as the task ends. However, mastery-goal orientation, which is desirable, is believed to generate motivation as an outcome (motivation to learn for the sake of learning). When mastery goals are adopted, pride and satisfaction are tied to successful effort and have been associated with a preference for challenging work and risk-taking and an intrinsic interest in learning activities. There are advantages to a mastery goal orientation: (a) 
individuals are oriented towards developing new skills; (b) they try to understand their work, improve their level of competence, and achieve a sense of mastery based on self-referenced standards. What does this tell us about classroom practices? Since mastery-goal orientation is desirable, what are the structures of the classroom environment that pave the way for it? As an answer to these questions, Ames $(1990,1992)$ argued that there are three factors that teachers should keep in mind if mastery goal orientation to develop: (a) the design of tasks and learning activities, (b) evaluation practices and use of rewards, and (c) distribution of authority or responsibility.

Concerning the design of tasks and learning activities, Ames $(1990,1992)$ argued that since students use assigned tasks to judge their ability, they should be cautiously designed to capture learners' interest. The tasks should involve variety and be based on meaningful reasons for students' engagement. Students should perceive the assignment as an opportunity to understand the content, empowering skills, or gain new skills. Malone (1987) described that challenge, interest, and perceived control as factors that ought to be implicit in the design of learning tasks. When students are offered personal challenges and a sense of control over the learning process and products, they are more likely to create an intrinsic purpose to learning. As to evaluation practices, the way students perceive evaluative information dictates the type of orientation goals they develop, which eventually elicits different patterns of motivation. When the evaluation is normative and stresses social comparison, it is more likely to affect students' motivation negatively. By comparing students' outcomes with others, students' focus shifts to winning, outperforming another rather than trying hard, improving their performance, or just participating. To cut it in short, for the evaluation to boost mastery goal orientation, it should target improvement, progress, and mastery; it should be private rather than public; it should provide opportunities for improvement by encouraging a view of mistakes as a sign of learning.

Finally, the distribution of authority and responsibility is another motivational factor. It is highly recommended that teachers provide enough room for students' participation in decision-making. Students should be given opportunities for selecting, designing (planning), and applying appropriate strategies. By giving students a chance to control their learning and develop autonomy interdependently with their instructors, teachers impart responsibility to them. For the choice to be guided by interest, not by an intent to minimize effort, protect feelings of self-worth, or avoid failure, the evaluation should not be normative, or else performance goal orientation will be encouraged.

The PW approach provides the necessary conditions for putting the above-mentioned motivational factors into effect. It is one of the reasons why educators adopt the approach in their teaching. Blumenfeld et al. (1991) stated that the integrative perspective on motivation and learning has led to new interest in student projects (p. 371). Unlike traditional teaching in which learners are pawns of external forces, PjBL classrooms offer learners opportunities to exert authority on their learning through investigations outside the classroom walls. Students choose a theme during PW tasks, design a plan, collect data, and evaluate the outcome. Emphasizing the critical role of the topic/theme and its motivating value in the project process, Legutke and Thomas (1991) claimed that learners should be provided with enough freedom to select the topics and methods of working (p. 236). Henry (1994) pointed out that the PW approach allows students to follow their interests and exert more control of the learning process. As a result, many students get very involved in PW and find their motivation for undertaking learning increases (p. 11).

However, Blumenfeld et al. (1991) indicated that PjBL is not likely to work unless projects generate and sustain students' motivation thoughtfulness (p. 375). According to the theory of motivation, people are unique individuals, and every person is motivated differently. Based on this, one holistic approach, along with one textbook, would not generate positive outcomes. Therefore, teachers in PjBL lessons provide learners with the choice because "students' choice is an important aspect of project work" (Fleming, 2000, p.9). 
"These choices need not be unlimited to be motivational" (Slavin, 2006, p.337). When students are given a chance to choose from a list of topics, the topics that meet their needs are usually preferred.

One of the critical features of PjBL is the content. The latter is highly recommended to be authentic and personal to foster motivation (Blumenfeld et al., 1991). Poupore (2014) investigated the influence of the content-related conditions on adult second language learners' task motivation during an interactive task. The results showed that content associated with immediate personal life themes such as personal growth, human relationships, and life challenges is perceived to be more intrinsically interesting than that associated with more remote and abstract topics (p. 69). In addition to content, teachers' motivation has been reported to affect students' motivation positively. Lam, Cheng, and Ma (2009) examined the relationship between teacher and student intrinsic motivation in PjBL. They concluded that the teacher's intrinsic motivation predicted students' intrinsic motivation directly and indirectly through instructional support mediation (p.566).

\subsubsection{Constructivisim}

Another insight from the literature supporting the PjBL approach has to do with constructivism. As is the case with all learning approaches, the PjBL approach is driven by assumptions and philosophies of education and how learning occurs. These theoretical and philosophies are in large part attributed to the constructivist theory of learning. Unlike traditional schools, where learning is reduced to a process of transmitting knowledge from teachers to students, constructivism assumes that learning is much more than memory. Students' contribution to the discovery of this knowledge is fundamental to effective learning. For students to understand and be able to apply knowledge, they must work to solve problems, discover things for themselves, and wrestle with ideas" (Slavin, 2006, p. 243). Largely, educational constructivism might be seen as a cognitive perspective on learning with a strong relation to the cognitive-developmental theories of Piaget, Vygotsky, and Bruner (Fetsco \& McClure, 2005).

While educational constructivists acknowledge that learners actively construct their knowledge rather than passively receiving it, there is no compromise as to the nature of knowledge and the process of knowledge construction (Fetsco \& McClure, 2005; Woolfolk, 2005). This disagreement is manifested in psychological constructivism with a strong connection with Vygotsky and Burner. The former believes that "knowledge exists in the mind of the learner in the form of mental structures, and that knowledge is constructed individually through the processes of assimilation, accommodation, and organization" (Fetsco \& McClure, 2005, p.142). The latter believes that "knowledge consists of cultural tools that exist in the social world before they are internalized, and that knowledge is internalized as a result of interactions with the social environment" (Fetsco \& McClure, 2005, p. 142). What does this disagreement tell us about classroom practices?

By putting all the social and psychological constructivism implications together, a shared list of the classroom practices might be developed. Fetsco and McClure (2005) developed a list of ideas that translate constructivists' views into educational practices:

- classrooms need to provide opportunities to discover new knowledge through problemsolving tasks;

- complex learning experiences should be integrated into the classrooms;

- classrooms should provide learners to think collaboratively both with other classmates and instructors;

- classrooms ought to encourage self-regulation so that learners can actively develop their own learning experiences;

- authentic learning should be encouraged so that it is easy for learners to enculturate into their outside communities. 
Similarly, Woolfolk (2005) listed other common elements of constructivist perspectives as follows. According to Woolfolk, classrooms should:

- embed learning complex, realistic, and relevant learning environment,

- provide for social negotiation and shared responsibility as a part of learning,

- support multiple perspectives and use various representations of content,

- nurture self-awareness and understanding that knowledge is constructed, and

- encourage ownership in learning (p. 319).

With the principles mentioned above in mind, the constructivism theory of learning can back up the PW approach to learning. Learning by doing is at the heart of the project method, entirely consistent with the core of the educational constructivist classroom practices. How does learning take place in a PjBL classroom? Fleming (2000) asserted that students are engaged in activities that are interesting to them through projects. Through projects, students are no longer hostage to that classroom. While students are intensively conducting their projects, they can incorporate community members and settings. Their tangible outcomes often result in an exhibition or a product for a real-world purpose or audience. This learning ownership and shared responsibility, and a realistic learning environment are at the center of constructivism.

According to Fleming (2000), "learning through projects is often associated with the constructivist theory of learning" (p.12). In the PjBL classrooms, teachers serve as facilitators, monitors, and guides. This teaching approach gives students opportunities to develop habits that they will use as lifelong learners.

\subsection{Culture Framework of the 3Ps}

In the National Standards, culture is introduced as the philosophical perspectives, behavioral practices, and society's products. The relation among these three cultural elements is represented in a triangle diagram with perspectives at the top and products and practices forming the base, showing how the products and practices are derived from the perspectives that shape a cultural group's worldview. This diagram also shows that these three components of culture are closely interconnected (Cutshall, 2012).

Figure Error! No text of specified style in document.

The Culture Triangle (Standards for Foreign language Learning in the 21sth Century, 2006, p. 74).

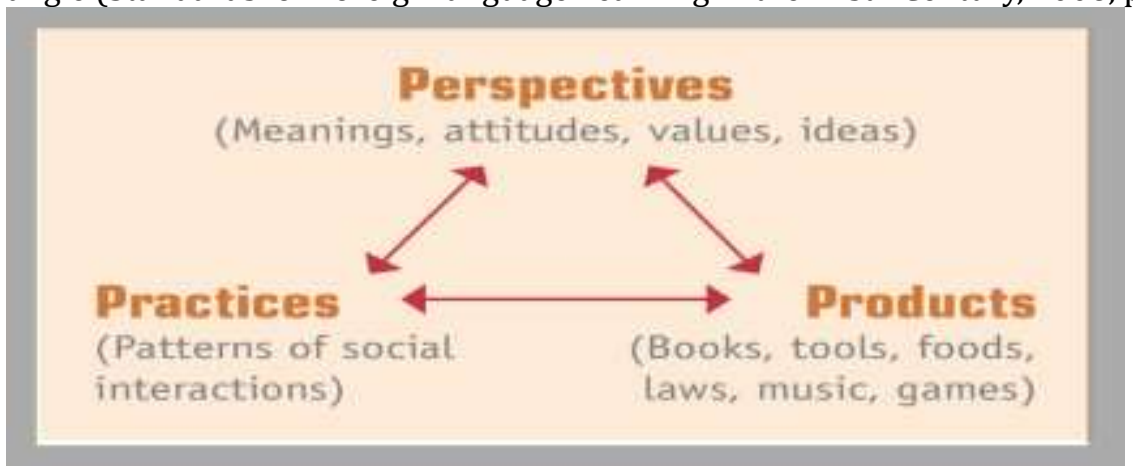

Moran's (2011) definitions of the above three dimensions of culture are adopted in this research study. According to Moran, cultural products are all the artifacts produced or adopted by the members of the culture. Cultural products range from tangible - such as tools, clothing, written documents, or buildings - to more elaborate yet still observable constructions such as written and spoken language, music, or complex institution of family, education, economy, politics, religion. Cultural products, both tangible and intangible, are located and organized in physical places. Cultural practices include the full range of actions and interactions that people of the culture carry out individually or with others. These include language and other forms of communication and self-expression, and activities associated with social groups, and the use of products. These practices are both verbal and non-verbal 
and include interpretation of time, space, and the context of communication in social situations. Practices also involve notions of appropriateness and inappropriateness, including taboos. As to cultural perspectives, they represent the perceptions, beliefs, values, and attitudes that underlie the products and guide persons and communities in the practices of the culture. They can be explicit, but often they are implicit, outside conscious awareness. Perspectives generally provide meaning and constitute a unique outlook or orientation toward life - a worldview.

\subsection{Previous research on PjBL and cultural awareness}

$\mathrm{PjBL}$ in the context of language education has been reported to help foreign language learners increase their understanding of other cultures. In the Chinese EFL context, Gu' (2002) 20 Chinese college students and 28 American junior college students worked in small groups to conduct investigations into business opportunities or cultural topics in China or America. The analysis of classroom observations, interviews, email messages, and other electronic texts revealed that Chinese students "have promoted their critical awareness of cultural differences (....) and they enjoyed learning from their American holidays and their education system" (p. 205). Similarly, in the Japanese university context, some of Bulach's (2003) research participants reported having gained some knowledge as to culture shock and changed some of their perspectives towards foreigners. This improved cultural awareness was also reported by Hsu's (2014) research subjects. Hsu asked 43 college students at a national university in northern Taiwan to collaboratively investigate the world festivals. The purpose was to identify the extent to which project-based instruction affects students' perceptions of the development of cultural knowledge. The data elicited through the questionnaires and interviews showed that the participants gained more understanding of other cultures. In the same vein, Liu et al. (2006) explored the learning benefits of an inquirybased module to enhance middle school students' awareness about Japanese culture, history, and geography through the topic of food. 64 sixth graders from two middle schools in the USA were required to create the food section of a Japan travel guide in small groups. The analysis of the electronic copies of their travel guide, along with post-content knowledge questionnaires, survey instruments, and interviews revealed that students enhanced their understanding of Japanese food and culture following their project completion. Ngo (2014) implemented PW in the teaching of intercultural communication at Vietnam National University. 20 master English-majored students explored four micro-project topics related to the cultural values of environmental protection. The interview-based findings demonstrated that the students learned about cultural values and behaviors towards the environmental protections among cultures. In Indonesia, Irawati (2015) elaborated on the application of cultural $\mathrm{PjBL}$ in the hope of helping students to develop their academic writing ability. 20 students were asked to work in small groups to compose essays on different cultural topics, and compile them into one mini-journal. The analysis of classroom observations, students' essay scores, and interviews indicated that students enhanced their cultural understanding as a result of being exposed to culture through PjBL. In the Moroccan context, Bouchouk (2017) asked 16 American high school students to explore some aspects of Moroccan cultures using PW to develop their cultural knowledge of the host country. Data from interviews exhibited that participants successfully enriched their cultural knowledge of the host country (Morocco). Finally, whether the PjBL approach helps students develop intercultural knowledge or not, Kim (2019) explored the potential of culture learning through PW for intercultural knowledge construction and its experiences within pre-service English teacher education. Based on the data elicited from group projects, weekly journals, and post-project written reflections, the findings exhibited that students "built deep and broad intercultural knowledge based on the four cultural topics" (p.8).

Following from the above, the review has shown that studies congruently concluded that their research participants enhanced their cultural understanding following 
their PW completion. However, the researcher in this study believes that their results seemed to have been incomplete, mainly because they haven't explained how PjBL managed to improve students' cultural awareness. Moreover, while all the researchers (Bouchouk, 2017; Hsu, 2014; Gu, 2002; Kim, 2019; Irawati, 2015; Liu et al., 2006; Ngo, 2014) all the reviewed studies consistently concluded that the PjBL approach has successfully led students to foster their cultural understanding, none of them has addressed the boundaries of this cultural understanding. This deficiency is also resonated by Hall (2012). Hall pointed out that "we still know little about the pedagogical effectiveness of the practices [PjBL, pragmatic ethnography, problem-posing approach] for expanding learners' communicative horizons. Arguing that they should be effective (...) is certainly not the same as documenting not only that they are effective but how they manage to be so as well" (p. 130). These limitations and shortcomings could be explained by the fact that the researchers (Bouchouk, 2017; Hsu, 2014; Liu et al., 2006; Ngo, 2014) did not use a specific cultural framework. Additionally, except for both Kim (2019) and Hsu (2014), Bouchouk (2017), Liu et al. (2006), and Ngo (2014) did not adopt a specific PW model, which made their use of PjBL far from being systematic. Prompted by these deficiencies, the researcher believes that research needs to be expanded to provide more evidence on the efficacy of PjBL in the development of students' cultural awareness. Hence, this research study aimed to investigate the effect of PjBL on the second-year Baccalaureate students' awareness of the English cultures in the Moroccan EFL context. To this end, the researcher used Stoller's (2010) seven-step process and the cultural framework of the 3Ps.

\subsection{Research Questions}

This study addressed two major questions:

1. How does project-based learning help students improve their cultural awareness?

2. How does project-based learning help students relate cultural products and practices to cultural perspectives?

\section{METHODOLOGY}

This research study investigates the effect of using the PjBL approach on students' awareness of their home cultures and the English ones. To meet this objective, the researcher used a quasi-experimental design. Two similar intact groups were pretested, administered two different treatments, and post-tested to assess their differences. Even if the quasiexperimental approach has the advantage of utilizing existing groups in educational settings, it still poses considerably more threats to internal and external validity, including threats of maturation, selection, mortality, and the interaction of selection (Creswell, 2012). Unless the effect of these variables is controlled, the causal inferences cannot be made using a quasiexperimental design. In other words, by controlling these variables, "the difference for the experimental group between pretest and posttest (if greater than that for the control group) cannot be explained by main effects of these variables" (Campbell \& Stanley, 1963, p. 48). Being conscious of shortcomings embodied in the threats posed on the internal and external validity (test effect, maturation, mortality, Diffusion of treatment), the researcher made every effort to minimize the potential threats to strengthen the study.

Figure 1

Research Design

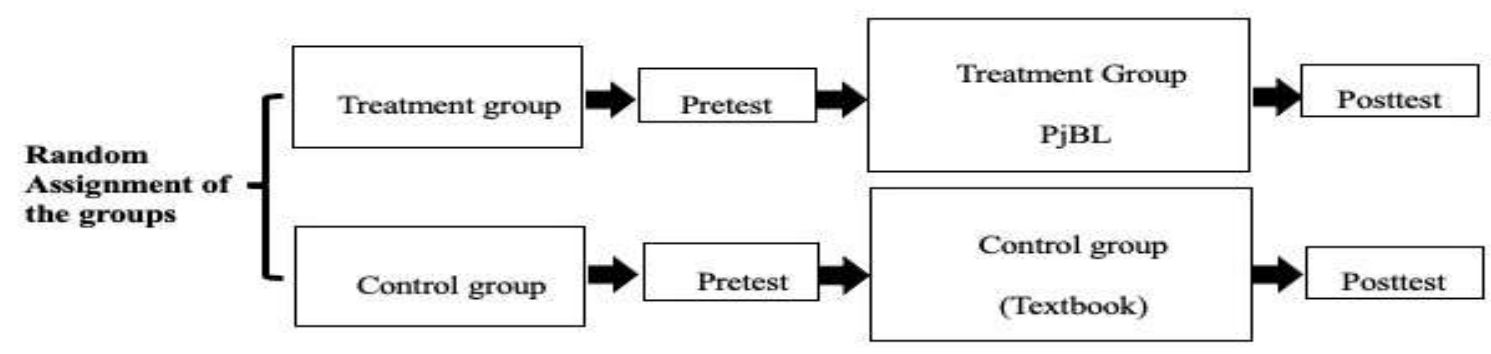




\subsection{Resaerch Participants and Setting}

The participants of this study were sixty-eight $(\mathrm{N}=68)$ second-year Baccalaureate students learning English as a foreign language at Annahda high school, Souss Massa Academy, Morocco, during the academic year (2018-2019). Even though the researcher did not randomly assign the individuals of the two intact groups (treatment group $(n=34)$ and control group $(n=34))$, they were very similar in several ways. First, before the study took place, the research participants had been exposed to general English courses through the same national ELT textbooks for three years. Second, the two groups belonged to the same stream (science), and they studied English three hours a week. Third, none of them had ever visited an English-speaking country. Finally, none of the participants had received English language and culture lessons in a language center other than public schools.

\subsection{Data Gathering Instruments}

\subsubsection{Cultural awareness test: purpose and content}

As mentioned earlier, the primary purpose of this research study was to measure the effect of PjBL on second-year-Baccalaureate students' cultural awareness of the English cultures in terms of cultural products, cultural practices, and cultural perspectives. Valette (1977) pointed out that:

Cultural awareness tests are typically administered in pairs: pretests and posttests. The pretest establishes the baseline or point of departure: how great is the students' cultural awareness before entering a course of study? The posttest allows the teacher to determine the degree of progress that students have made. (p. 182)

To measure how similar or different both the experimental and the control groups were with regard to their level of cultural awareness before the treatment, all the research participants took a self-developed cultural awareness test. Then, after six months of treatment, the two groups took the same cultural awareness test to identify whether they experienced progress in terms of cultural awareness level or not.

The cultural awareness test developed for this study revolved around five thematic units purposefully taken from the three ELT textbooks used to teach English to the secondyear Baccalaureate students in the Moroccan EFL context. The thematic units were (1) formal, informal, and non-formal education, (2) cultural issues and values, (3) women and power, (4) humor, and finally (5) science and technology. Each of these units addressed a number of culture standards, along with the other four Cs standards, which teachers are required to address in their EFL classroom practices. Because some of the culture standards suggested in the three textbooks were too broad, the researcher defined them and added others for the sake of richness and priority. Moreover, even though the English language has become a lingua franca, the researcher intentionally restricted the target cultures to the American and British cultures for two significant reasons. First, for research purposes, it was hard to include world cultures. Second, the fundamental purpose of the study was to measure the effect of the PjBL approach on students' cultural awareness, which means it did not matter which cultures were chosen.

Using multiple-choice as a test method, the researcher developed 103 items to test the research subjects' knowledge of the English cultures with specific reference to five themes in terms of cultural products, practices, and perspectives. For each test item, three distractors were provided. Before developing the cultural awareness test items, four essential criteria were taken into consideration. The first criterion was the research participants' language ability. The second one was the cultural framework of the 3Ps. The third one was the basic cultural knowledge content. The fourth one was the dynamic nature of culture. 
Table 1

Thematic Units, cultural objectives and The Distribution thematic of Test Items Number by Types of Culture

\begin{tabular}{|c|c|c|c|c|c|}
\hline \multirow[b]{2}{*}{ 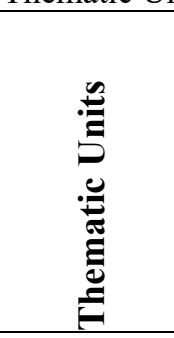 } & \multirow[b]{2}{*}{ Cultural objectives } & \multicolumn{4}{|c|}{$\begin{array}{l}\text { The Number of Test } \\
\text { Items }\end{array}$} \\
\hline & & 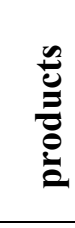 & 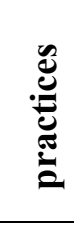 & 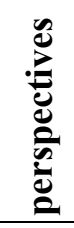 & 矛 \\
\hline 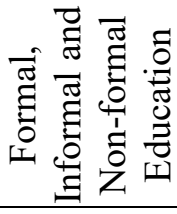 & $\begin{array}{l}\text { 1-To know about illiteracy in the UK and the USA. } \\
2 \text {-To know about the system of education in the USA and } \\
\text { the UK. }\end{array}$ & 6 & 9 & 3 & 18 \\
\hline 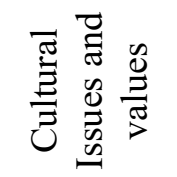 & $\begin{array}{l}\text { 1-To learn about marriage traditions in the US and the UK. } \\
\text { 2-To learn about a celebration in the USA and the UK. }\end{array}$ & 6 & 9 & 9 & 24 \\
\hline 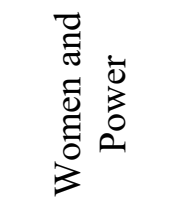 & $\begin{array}{l}\text { 1-To know about women in the UK and the USA. } \\
\text { 2-To know about the roles of women in the UK and the } \\
\text { USA. }\end{array}$ & 9 & 9 & 3 & 21 \\
\hline 官 & $\begin{array}{l}\text { 1-To learn about humorists in the USA and the UK. } \\
\text { 2-To know about the types of humor. } \\
\text { 3-To know about humor festivals in the USA and the UK. }\end{array}$ & 9 & 3 & 6 & 18 \\
\hline 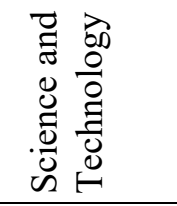 & $\begin{array}{l}\text { 1-To know about Internet penetration, Internet addiction in } \\
\text { the USA and the UK. } \\
2 \text {-To know about online shopping culture in the USA and } \\
\text { the UK. }\end{array}$ & 7 & 12 & 3 & 22 \\
\hline & Total & 37 & 42 & 24 & 103 \\
\hline
\end{tabular}

\subsubsection{Validity and reliability of the test}

"If researchers' interpretations of data are to be valuable, the measuring instruments used to collect those data must be both valid and reliable" (Gay, et al., 2012, p. 160). "Validity refers to whether a measure is truthful or genuine. In other words, a measure that is valid measures what it claims to measure" (Jackson, 2009, p. 70). For the researcher to check the validity of the test in terms of item appropriateness, structural accuracy, and relevance to the research purpose, two experts - Professor Fredricka L. Stoller, Professor Emerita at the English Department in Northern Arizona University, and Professor Mike Byram at Durham University in the UK proofread the test. The two professors proofread the test for language accuracy, content validity, and clarity. For more validity, the test was read by some native speakers of English. Likewise, to ensure that the test items were understandable, well-defined, and appropriate, a similar group to the experimental and control groups in the same research setting took the test.

Another element that helps achieve the quality of experimental research is the reliability of the research instruments used. Reliability refers to the consistency of a measurement technique, and it is concerned with the consistency or stability of the score obtained from a measure over time and across settings or conditions (Creswell, 2012; Gay, et al.,, 2012; Muijs, 2010; Marczyk, et al.,, 2005). Cronbach's Alpha Reliability approach was employed to determine how all items on the test were related to all other test items using the 
SPSS software version 23. As Table 2 illustrates, the reliability coefficient for the pretest yielded $\alpha=0.75$. According to the following guidelines suggested by Cohen, Manion, and Morrison (2002): $>0.90$ very highly reliable / $0.80-0.90$ highly reliable / $0.70-0.79$ reliable / $0.60-0.69$ marginally/minimally reliable $/<0.60$ unacceptably low reliability, the reliability of the cultural awareness test was reliable to use in the research study.

Table 2

Cronbach's Alpha Reliability Results

$\begin{array}{lll}\text { Cronbach's Alpha } & \begin{array}{l}\text { Cronbach's Alpha Based on } \\ \text { Standardized Items }\end{array} & \text { Number of Items }\end{array}$

\begin{tabular}{lll}
\hline .755 & .754 & 103
\end{tabular}

\subsection{Research Procedure}

As already stated in the research design section, both groups were taught the same cultural content differently. While the experimental group students were introduced into the English cultures through $\mathrm{PjBL}$, those in the control group were presented into the same cultures through the textbook in use. In terms of cultural content, it's worth highlighting that because the PjBL students had to systematically explore the cultural content outside the classroom on their own through a wide variety of authentic materials, their exposure to culture is open and unrestricted. That is, they might learn about things that the researcher had not anticipated. On the other hand, the control group students' exposure to culture was restricted to reading materials featured in the textbook, teacher's handouts, teacher's comments, and in-class discussions.

In light of the different cultural goals addressed in the five thematic units, the researcher constructed five projects on five different themes (macro-projects), adopting the seven-step process proposed by Stoller $(2010,2012,2014)$. According to Stoller's refined PjBL model, for PW to successfully enhance content knowledge, promote language learning, and develop real-life skills, it ought to systematically go through three major stages, each of which involves a number of steps. Informed by the necessity of students' choice in generating motivation and interest in the research topics, the researcher provided students with a list of sub-themes to choose from. All the sub-topics suggested were so complementary that they treated the general thematic units from different angles (for samples of a macro-project and a micro-project). For the researcher to maintain parity of cultural content between the control and treatment groups, all the sub-topics explored by the treatment group were usually presented to the control group students through reading activities. Because the textbooks had a limited amount of cultural content, the researcher provided more supplementary handouts. Although the two groups differed in the ways they received the same cultural content, they spent the same commensurate time learning about the English cultures with specific reference to five thematic units.

After the cultural awareness pretest was administered to measure the existing difference between the two groups concerning their cultural awareness levels before the treatment, the researcher embarked on the experiment. Below is the detailed implementation of the culture lessons through $\mathrm{PjBL}$ and the textbook.

\subsubsection{The PjBL Group (Treatment group)}

\section{Preliminary stage (steps 1 to 3 ).}

Beckett (2002) pointed out that the instructor may have incredible goals to achieve. Still, if their students do not see the benefit of what and how they were asked to learn, their goals cannot be achieved, and their educational agenda may be jeopardized. Also, if the goals and benefits are clear from the outset, it is more likely to fuel learners' motivation to embark on the projects as their motivation and commitment is what generally drives a project forward and determines its overall success (Fried-Booth, 2002). Prompted by the necessity of being explicit about the project goals and their impact on students' motivation and commitment, the 
instructor during week one explicitly highlighted the learning benefits that can accrue from working on cultural projects. As the research participants in this study had never been systematically exposed to $\mathrm{PjBL}$ before this research took place, the instructor briefly introduced the approach in terms of its learning benefits, the seven steps, the teacher's and the students' roles, etc.

Because the content of the projects was about culture, the instructor briefly cast some light on the utility of having some familiarity with the English cultures. The instructor also stressed that students' awareness of the culture of the people whose language they were learning could immensely help them communicate effectively and appropriately with native speakers. Having emphasized culture in EFL learning, the researcher informed the research subjects that the limited time budget, the culture of assessment, and the linguistically overloaded textbooks make it difficult to learn about those cultures. Thus, one way to learn about cultures was through projects precisely, as almost $80 \%$ of the work is done outside the class. Finally, to ease students into their PW tasks, samples of students' end-products completed by previous students were shared.

Furthermore, during the preliminary stage, the researcher introduced the 3Ps framework to students. To help students grasp the meaning of cultural products, cultural practices, and cultural perspectives, the researcher gave various examples from students' home and the English cultures, followed by a task to check their understanding. Below is the culture teaching procedure through the seven-step process.

\section{Step 1: The students chose their project themes (week 1)}

The researcher asked the participants to form groups of five to six students. Because the class was heterogeneous and because one of the objectives of the culture projects was to encourage cooperation among learners, group members were formed based on students' abilities and learning facilities. Each group included at least one student who is good at computing, one who is good at writing, one who is good at speaking, and one who has a computer at home. As soon as the groups were shaped, the researcher introduced the goals of the projects and shared the seven-step process on handouts. Although it is highly recommended that instructors should allow students total freedom to decide on their research topics, this decision was made by the researcher in this study partly because the culture topics had to reflect the cultural awareness pretest content and partly because the project themes were purposefully chosen from a ten pre-determined thematic units listed in the textbooks inuse: Gateway to English (Hassim, Blibil \& Rasmy, 2007), Insights into English (Najbi \& El Haddad, 2007), and Ticket to English 2 (Hammani, Ahssen \& Tansaoui, 2007). However, for the researcher to give some freedom to the research participants, each of the five thematic units was broken down into five or six sub-topics (micro-projects) that treated the general themes from different perspectives. For example, the first thematic unit on formal, informal, and non-formal education was broken down into six sub-topics: (1) proms in the USA and the UK, (2) private schools vs. public schools in the USA and the UK, (3) illiteracy in the USA and the UK, (4) dropping out of school in the two countries, (5) school systems in the USA and the UK, (6) higher education in the USA and the UK.

\section{Step 2: The students determine the outcome of the project (week 1).}

As soon as the small groups singled out their project themes based on their interest, they decided on tangible outcomes of their projects. To help with this process, the researcher displayed a wide variety of different forms that the end-products can take (e.g., bulletin board display, written report, debate, brochure, oral presentation, video, PPT presentation, theatrical performance). Based on their language needs (speaking and writing), all the groups agreed on posters and 20-minute PPT presentations to supplement them. Because the research subtopics were different, all the groups were required to design a small quiz at the end of their PPT presentations. These quizzes were meant to encourage the audience to value the cultural 
information presented by paying attention during the oral presentations. The first person who answered all the questions was given a short story as a prize.

\section{Step3: Students and instructor structure the project (week 2).}

After the group members agreed on the project themes and the end-product forms, the instructor asked them to meet outside the classroom to structure their projects. To help with this process, the researcher provided each group with a different list of suggested stimulus questions that served as a guide during the data gathering process. The questions addressed three types of culture: cultural products, cultural practices, and cultural perspectives. While the questions were not linguistically demanding, they were meant to encourage students to relate the 3Ps to one another and draw their attention to similarities and differences among the three cultures. In so doing, students could have a deeper understanding of the cultural issues having been explored. Although the researcher proposed the guided questions, the groups were allowed to add other questions. Also, during the out-of-school meetings, students decided on their primary roles and responsibilities. The instructor suggested that role assignments should consider students' abilities, interests, and learning facilities. To maintain communication outside the classroom, each group member created WhatsApp and Facebook groups. To equalize the workload, the researcher encouraged students to pair up with others to help at different stages of the projects. With the deadline for the end-product in mind, students agreed on the sequencing of project tasks. For the researcher to share and elucidate the significant performances that were going to be assessed during their PW tasks, assessment checklists were given to the groups. Through those checklists, cultural content, types of culture, language and public speaking skills, and the use of ICT were assessed by the audience and the instructor.

\section{Information gathering, compiling and analyzing, and reporting (steps 4-6)}

\section{Step 4: Information gathering cycle (week 3 through week 4)}

This stage was cyclical as it oscillated between language intervention sessions and information gathering. Since projects were done outside the classroom, the researcher provided the research subjects with the language skills necessary to locate cultural information easily. Given that English is not spoken outside the classroom and that the area where the research study was conducted is not a tourist city, the most accessible source of cultural information for students was the Internet. Therefore, the instructor provided learners with some precise and pertinent phrases and expressions they could use while browsing the net for specific information. The instructor also supplied groups with various links to some reliable websites to obtain cultural information about the topics under exploration. As students were more likely to gather information from reading authentic materials and watching YouTube videos, the instructor provided a language intervention session on notetaking skills, listening/reading for the gist, and listening/reading for details. In addition to this, the researcher gave the research participants a list of common words associated with the research themes under exploration in Arabic and English.

\section{Step 5: Information compilation and analysis Cycle (week 5)}

After the groups gathered the cultural information for their research projects using the stimulus questions as guidance, they were asked to compile it and analyze it in line with the goals of their projects in mind. Before students started to compile and analyze the data gathered, the instructor had prepared students for the language demands of the two processes by providing another language intervention session on data synthesizing techniques. During the language intervention, the researcher taught students how to distinguish relevant information from irrelevant one, pull together information from various sources in a chart, and paraphrase ideas picked out from texts. Also, the researcher supplied students with a list of connectors used in comparing and contrasting ideas.

Step 6: Information reporting cycle (week 6) 
After students compiled information, they handed in their posters and emailed their PPT presentations to be proofread by the instructor. After proofreading, feedback on both language and the accuracy of the cultural content of the projects were given to each group during school recess time and on Facebook chat boxes. Students were given enough time outside the classroom to review their posters bearing in mind the teacher's comments. With the purpose of preparing students for the oral presentations, small intervention sessions were provided on manners of presentation, including eye contact, voice projection, body language, pauses, starting from general to specific, and the use of visual aids. During this step, students presented their tangible outcomes in front of their classmates. Before the presentation, the audience, including the instructor, were given the same assessment checklists delivered during step three to assess the presenters' performance using smiley faces. Right after the end-products were shared, the presenters collected those checklists to be used as feedback to improve their future PW. Each presentation lasted 20 minutes to 30 minutes, sometimes more. Given the duration of the presentations and the number of groups (six), the researcher went for more extra classes so that all the research participants could have a chance to present their tangible outcomes.

\section{Evaluating the projects}

\section{Step 7: Evaluating the project (week 6)}

At the end of every project, for the researcher to keep records on individual learning during the culture projects, all the treatment group students were asked to complete the reflective reports. To help with this process, the researcher offered the participants reflection sheets. These sheets included a set of questions to answer outside the classroom and return them to the instructor to be exploited for the data gathering and analysis. Through those reports, students were encouraged to reflect on the cultural content learned, the language learned, the skills improved, strategies perfected, and the challenges they encountered. More specifically, individuals reflected on what they knew that they had not known before the projects, what they could do that they had not been able to do before the projects, what skills they learned, what they could do to improve their projects in the future. Again, Arabic was allowed to incite participants to answer questions without being discouraged by the language.

\subsubsection{Textbook group (the Control group)}

After the control-group students had taken the cultural awareness pretest, they were introduced to the English cultures. To motivate students to learn about the cultures, the researcher informed them about the positive effects of having some familiarity with the English cultures on their communicative competence. Then, using illustrations and examples from both students' homes and the English cultures, the researcher carefully explained the three elements of culture (the 3Ps) and how they are interconnected. The students were also informed that culture learning is a part of their general English course and should be treated equally like grammar, functions, writing, etc.

Because the three textbooks had a limited amount of cultural content, the researcher supplemented them with more reading materials from the Internet and other commercial textbooks. The researcher usually assigned those reading texts as homework. In the classroom, the whole-class correction technique was typically used. In the post-reading stage, the instructor invited students to open-class discussions. During this stage, the researcher drew students' attention to similarities and differences with reference to cultural products, practices, and perspectives among the English cultures. It's worth mentioning that the instructor dominated the discussion, especially when it comes to perspectives. As soon as the students had read about a cultural sub-topic, the researcher assigned another reading text on a different sub-theme. 


\section{DATA ANALYSIS AND STATISTICAL PROCEDURES}

\subsection{Pre- and posttest cultural awareness}

After the research subjects took the multiple-choice pre- and posttests on cultural awareness, their answers were scored carefully and manually by the researcher. After scoring all the tests, the researcher rechecked every fourth item in an attempt to minimize errors. The following scoring system was used: each test item was worth 1 point. Correct answers received 1 point, and incorrect answers received 0 point. Before the data was entered into SPSS, they were coded using the following coding criteria: The correct answers and the wrong answers were assigned numeric values of 1 and 0 , respectively. The control and experimental groups' total scores on the pre- and posttest were calculated by adding up the total number of correct answers.

Similarly, to identify students' performance on the 3Ps (products, practices, and perspectives), their pre- and posttest scores on the 3Ps were computed by adding up their correct answers. Using the total scores, the researcher calculated each group's standard deviation and the means for both pre- and posttest scores by general cultural awareness and by types of culture (3Ps). To test whether there is a statistically significant difference between the means in the experimental and the control groups on the posttests at a selected probability level $\alpha \leq .05$, the researcher used the independent sample t-test. The independent-groups $t$ test is a parametric statistical test that compares the means of two different samples of participants. It shows whether the samples perform so similarly that we conclude they are likely from the same population or whether they perform so differently that we conclude they represent two different populations (Jackson, 2009).

\section{FINDINGS}

\subsection{Overall cultural awareness: pretest results}

A pretest was administered to the control and experimental groups to gauge the research participants' general cultural awareness of the American, British, and Moroccan cultures. Table 3 presents the pre-cultural awareness mean scores and standard deviations of students in the two groups before the treatment.

Table 3

The Overall Cultural Awareness Pretest Mean Scores and the Standard Deviation

\begin{tabular}{llllll}
\hline & Groups & N & Mean & Std. Deviation & Std. Error Mean \\
\hline \multirow{2}{*}{ Pretest } & Contr_group & 34 & 47.03 & 8.476 & 1.454 \\
\cline { 2 - 6 } & Exper_group & 34 & 46.21 & 7.053 & 1.210 \\
\hline
\end{tabular}

Note. Contr_group $=$ control group. Exper_group $=$ Experimental group

Table 3 shows that the mean score $(M)$ for the control group was 47.03, and 46.21 for the experimental group. The two mean scores for the two groups were very close. The standard deviations $(S D)$ displayed that the variation in the spread of scores was very slightly wider for the control group $(S D=8.476)$ than the experimental group $(S D=7.053)$. To determine whether a statistically significant difference existed between the two groups' scores regarding their overall cultural awareness of the English cultures before the treatment, an independent sample $t$-test was run. Table 4 compares the cultural awareness pretest mean scores of students in the experimental group with those of students in the control group.

Table 4

Comparison of Pretest Cultural Awareness Scores 


\begin{tabular}{|c|c|c|c|c|c|c|c|c|}
\hline & & \multicolumn{4}{|c|}{$\begin{array}{l}\text { Levene's Test for } \\
\text { Equality of Variances }\end{array}$} & \multicolumn{3}{|c|}{ t-test for Equality of Means } \\
\hline & & $F$ & Sig. & $t$ & $d f$ & $\begin{array}{l}\text { Sig. (2- } \\
\text { tailed) }\end{array}$ & $\begin{array}{l}\text {-Mean } \\
\text { Difference }\end{array}$ & $\begin{array}{l}\text { Std. Error } \\
\text { Difference }\end{array}$ \\
\hline pretest & $\begin{array}{l}\text { Equal variances } \\
\text { Assumed }\end{array}$ & 1.472 & .229 & .435 & 66 & .665 & .824 & 1.891 \\
\hline pretest & $\begin{array}{l}\text { Equal variances not } \\
\text { assumed }\end{array}$ & & & .435 & 63.889 & .665 & .824 & 1.891 \\
\hline
\end{tabular}

The output from the independent sample $t$-test displays that the significance level was $.665($ sig $=.665)$. Since .665 is bigger than the standard alpha level $(p<.05)$ the researcher had pre-selected for the level of significance, there was no statistically significant difference between the control group students' cultural awareness scores and those of the experimental group students before the treatment. These results suggested that the two groups had similar cultural awareness level of the English cultures before the experiment. In order to assess the awareness of students from the two groups with respect to cultural products, cultural practices, and cultural perspectives, their pretest scores were compared. Table 5 presents the obtained test scores by types of culture.

\subsection{Overall cultural awareness: posttest results}

Table 5

Descriptive Statistics of Posttest Mean Scores and Standard Deviations

\begin{tabular}{llllll}
\hline & Groups & N & Mean & Std. Deviation & Std. Error Mean \\
\hline \multirow{2}{*}{ Posttest } & Exper_group & 34 & 75.06 & 8.873 & 1.522 \\
\cline { 2 - 6 } & Contr_group & 34 & 58.35 & 8.366 & 1.435 \\
\hline
\end{tabular}

Table 5 presents the descriptive statistics of the cultural awareness posttest average scores and the standard deviations. From the data output, the mean score of the experimental group $(M=75.06)$ was remarkably higher than the one for the control group $(M=58.35)$. However, their observed standard deviations were close, indicating that scores of students from the two groups were close to the observed averages. A statistical analysis using the independent samples $t$-test was employed to decide if the observed difference between the mean scores was statistically significant. Table 6 presents the two observed posttest mean scores comparison.

Table 6

Comparison of Posttest General Cultural Awareness Average Scores Levene's Test for Equality $t$-test for Equality of Means
of Variances

\begin{tabular}{|c|c|c|c|c|c|c|c|c|}
\hline & 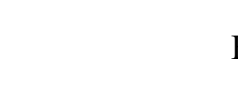 & & Sig. & $\mathrm{t}$ & $\mathrm{df}$ & $\begin{array}{l}\text { Sig. (2- } \\
\text { tailed) }\end{array}$ & $\begin{array}{l}\text { Mean } \\
\text { Difference }\end{array}$ & $\begin{array}{l}\text { Std. Error } \\
\text { Difference }\end{array}$ \\
\hline \multirow{2}{*}{ Posttest } & $\begin{array}{l}\text { Equal variances } \\
\text { assumed }\end{array}$ & .078 & .781 & 7.988 & 66 & .000 & 16.706 & 2.091 \\
\hline & $\begin{array}{l}\text { Equal variances } \\
\text { not assumed }\end{array}$ & & & 7.988 & 65.773 & .000 & 16.706 & 2.091 \\
\hline
\end{tabular}

Table 6 on inferential statistics above displays that the $t$-value was found to be $t$ (66) $=7.988, p<.05$. According to these findings, it can be said that a statistically significant difference existed between the mean scores of the two groups at the pre-selected probability level of .05. This existing difference was expected, given the observed posttest average scores were substantially wider in favor of the experimental group. The posttest results reveal that the experimental group considerably outperformed the control group in terms of cultural awareness. 


\subsection{Cultural awareness by types of cultures: Pretest results}

Table 7

Pretest Scores and Standard Deviations by Types of Culture.

\begin{tabular}{llllcc}
\hline Types of culture & Groups & N & Mean & Std. Deviation & Std. Error Mean \\
\hline \multirow{2}{*}{ Products } & Contr_group & 34 & 17.91 & 3.957 & .679 \\
\hline \multirow{2}{*}{ Practices } & Exper_group & 34 & 18.35 & 3.365 & .577 \\
\hline \multirow{2}{*}{ Perspectives } & Contr_group & 34 & 18.29 & 3.589 & .616 \\
\cline { 2 - 6 } & Exper_group & 34 & 17.71 & 3.597 & .617 \\
\hline
\end{tabular}

Note. Contr_group $=$ Control group. Exper_group $=$ Experimental group

The cultural awareness pretest scores with reference to cultural products, cultural practices, and cultural perspectives are presented in Table 7. From the chart, it is clear that the mean scores of the two groups were very close. As to the cultural products, the mean scores for the control and the experimental groups were 17.91 and 18.35, respectively. Concerning cultural practices, the mean scores for the control and experimental groups were 18.29 and 17.71. Regarding cultural perspectives, the mean scores for the control and the experimental groups were $M=10.82$ and $M=10.15$, respectively.

Additionally, the data on standard deviations indicate that the distribution of students' scores in the two groups was almost the same for both cultural products and practices. At the same time, it was very close for the cultural perspectives. What do these figures suggest? Simply, the two groups were very similar at the level of their knowledge of cultural products, practices, and perspectives before the experiment. To determine whether these slight differences were statistically significant, an independent sample $t$-test was run. Table 8 compares the scores of the two groups at the level of the 3Ps.

Table 8

Comparison of the Pretest Mean Scores at the Level of the 3Ps.

\begin{tabular}{|c|c|c|c|c|c|c|c|c|}
\hline & & \multicolumn{7}{|c|}{$\begin{array}{l}\text { Levene's Test for } \\
\text { Equality of } \\
\text { Variances }\end{array}$} \\
\hline & & $\mathrm{F}$ & Sig. & $\mathrm{T}$ & $\mathrm{df}$ & $\begin{array}{l}\text { Sig. (2- } \\
\text { tailed) }\end{array}$ & $\begin{array}{l}\text { Mean } \\
\text { Difference }\end{array}$ & $\begin{array}{l}\text { Std. Error } \\
\text { Difference }\end{array}$ \\
\hline \multirow{2}{*}{ products } & $\begin{array}{l}\text { Equal variances } \\
\text { assumed }\end{array}$ & .726 & .397 & -.495 & 66 & .622 & -.441 & .891 \\
\hline & $\begin{array}{l}\text { Equal variances not } \\
\text { assumed }\end{array}$ & & & -.495 & 64.341 & .622 & -.441 & .891 \\
\hline \multirow{2}{*}{ practices } & $\begin{array}{l}\text { Equal variances } \\
\text { assumed }\end{array}$ & .127 & .723 & .675 & 66 & .502 & .588 & .871 \\
\hline & $\begin{array}{l}\text { Equal variances not } \\
\text { assumed }\end{array}$ & & & .675 & 66.000 & .502 & .588 & .871 \\
\hline \multirow{2}{*}{ perspectives } & $\begin{array}{l}\text { Equal variances } \\
\text { assumed }\end{array}$ & 4.967 & .029 & .899 & 66 & .372 & .676 & .752 \\
\hline & $\begin{array}{l}\text { Equal variances not } \\
\text { assumed }\end{array}$ & & & .899 & 59.459 & .372 & .676 & .752 \\
\hline
\end{tabular}

The pretest mean scores of both groups are compared in Table 8 . The significance levels of the $t$-test $(p=622, p=502, p=372)$ indicate that the differences among the means $(-441,588,676$ respectively) were very small. Because $(p=622, p=502, p=372)$ was larger than the pre-selected alpha level .05, this shows that a statistically significant difference did not exist between products scores, practices scores, and perspectives scores of the control group and those of the experimental group before the experiment. Table 9 presents the two groups' mean scores by the target culture. 


\subsection{Cultural awareness by types of cultures: Posttest results.}

Table 9

Posttest Scores and Standard Deviations by Types of Culture.

\begin{tabular}{llllll}
\hline Types of culture & Groups & N & Mean & Std. Deviation & Std. Error Mean \\
\hline \multirow{2}{*}{ products } & Exper_group & 34 & 26.94 & 3.676 & .630 \\
\cline { 2 - 6 } practices & Contr_group & 34 & 23.88 & 3.540 & .607 \\
\hline \multirow{2}{*}{ perspectives } & Exper_group & 34 & 27.79 & 4.531 & .777 \\
\cline { 2 - 5 } & Contr_group & 34 & 19.82 & 3.186 & .546 \\
\hline & Exper_group & 34 & 20.32 & 2.471 & .424 \\
\hline
\end{tabular}

Table 9 shows that the mean cultural products score for the experimental group was higher than that for the control group ( $M=26.94$ vs. $M=23.88$ respectively). The standard deviations of the two groups $(S D=3.676$ for the experimental group vs. $S D=3.540$ for the control group) were very close, indicating that there was not much more variability among the experimental group than among the control group. Concerning cultural practices, the descriptive statistics display that the average score for the experimental group was higher than that for the control group ( $M=27.79$ and $M=19.82$, respectively). The experimental group's standard deviation was slightly higher than that of the control group ( $S D=4.531$ vs. $S D=3.186$, respectively). Although the difference was not large, the small difference reveals that the students' scores in the control group were closer together than those in the experimental group. Finally, the data demonstrate that the experimental group's average performance $(M=20.32)$ on cultural perspectives was also higher than that of the control group $(M=14,65)$. However, their observed standard deviations $(S D=2.471$ for the experimental group and $S D=3.592$ for the control group) were not largely different. Taken as a whole, the observed average scores suggest that experimental-group students had considerably outperformed those in the control group regarding cultural knowledge of the 3Ps - cultural products, cultural practices, and cultural perspectives. So as to identify whether the differences among the observed mean scores were statistically significant or not, an independent sample $t$-test was utilized.

Table 10

The Comparison of Posttest Mean Scores by Types of Culture

Levene's Test for
Equality of $t$-test for Equality of Means
Variances

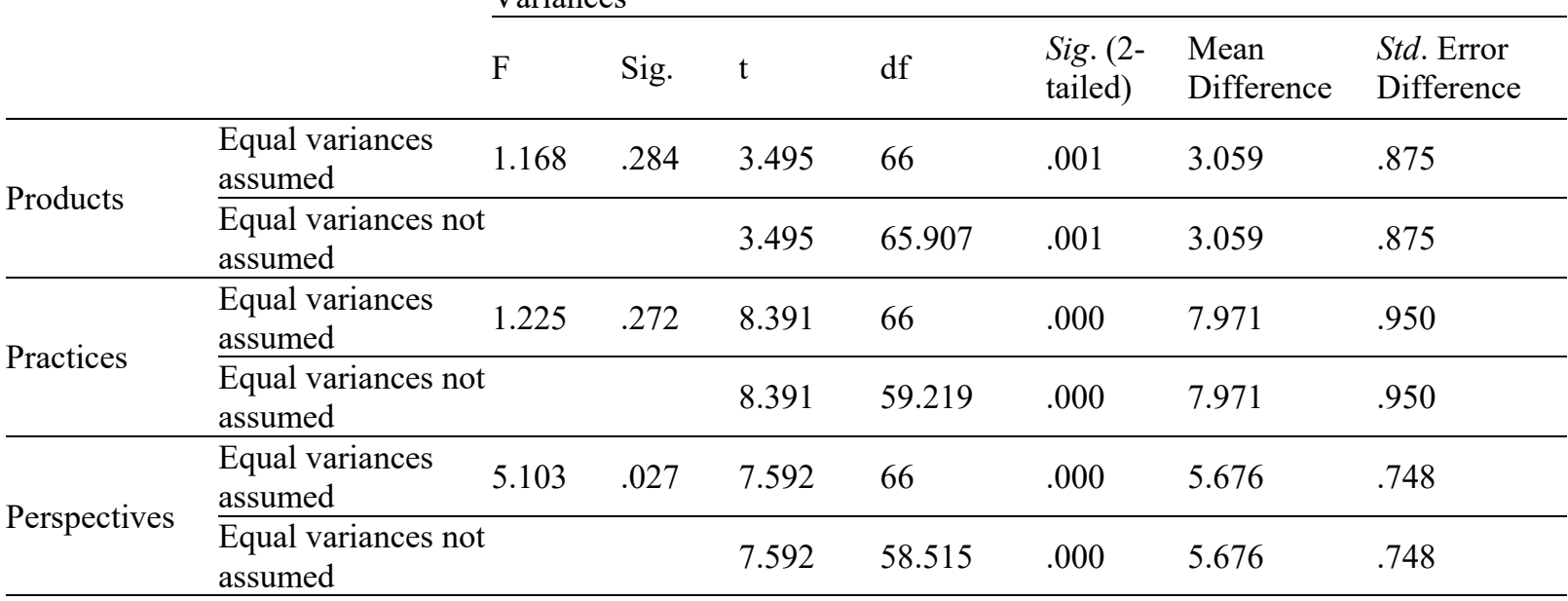

The data output on cultural products, practices and perspectives demonstrate that the observed $t$-values were positive in favor of the experimental group (the cultural products $t$ value $(66)=3.495, p<.05$, the cultural practices $t$-value $(66)=8.391, p<.05$ and the cultural 
perspectives $t$-value $(58,515)=7.592, p<.05)$. According to these inferential statistics, there was a statistically significant difference between the cultural products, practices, and perspectives average scores in the experimental group and those of the control group. The experimental-group students have significantly improved their cultural awareness of products, practices, and perspectives following the project completion.

\section{DISCUSSION}

As stated earlier in this study, students' cultural awareness was investigated at the level of general/overall cultural awareness and awareness by types of cultures. Based on the pre-cultural awareness test findings, there was no statistically significant difference in the mean scores between the two groups. These results suggest that participants' overall cultural awareness levels with regard to the five thematic units were similar before the treatment. Nevertheless, the post-cultural awareness test findings exhibited a statistically significant difference in the two groups' mean scores. More specifically, the research participants who were systematically led to explore the cultural topics through the seven-step process significantly outperformed those in the control group. Unlike the textbook students, those in the treatment group significantly increased their overall cultural awareness level.

With respect to students' knowledge by types of culture, the statistical analysis of the pre-cultural awareness test scores suggests that the differences between the treatment and control groups were not statistically significant. However, the post-cultural test scores analysis exhibited that statistically significant differences existed in favor of the experimental-group students. The researcher believes that the observed significant difference in favor of the experimental group has been attributed to the effect of the PjBL approach. While the control group students' exposure to culture was solely restricted to in-class learning materials, the treatment group students were systematically guided in small groups through the seven-step process to learn about the same cultural content from various authentic materials outside the classroom. After the treatment-group students have been exposed to culture through multiple authentic sources outside the classroom for six months, they were provided with the opportunities to invest more time learning about the five thematic units. The researcher believes that both time and massive exposure to more content might have contributed to the development of students' overall cultural awareness among students from the treatment group.

Another significant finding was the treatment group students' development of a deeper understanding of the cultural issues explored through the seven-step process. Unlike the students from the control group, those from the treatment group were able to profoundly enhance their cultural awareness of the English cultures at the level of cultural products, cultural practices, and cultural perspectives. While the control group students insufficiently improved their knowledge of the 3Ps through the in-class reading activities, open-class discussions, and teachers' comments, those from the treatment group developed it independently with the teacher's guidance through PW. The instructor's carefully-designed stimulus questions played a significant role in grabbing the treatment group students' attention to the types of culture. During the data gathering, compiling, and synthesizing stages of PjBL, students were encouraged to link the cultural products to cultural practices and cultural products to cultural perspectives. In so doing, students' knowledge of the target cultures revolved not only around factual information and cultural practices but also around the underlying values, attitudes, perceptions, and beliefs held by the members of those cultures. The opportunity to reflect on cultural products and cultural practices and the way in which cultural perspectives govern the two were believed to have helped the experimental group students, unlike the control group, to develop an in-depth understanding of the target cultures.

The treatment group students' attainment of a deeper understanding of the cultures consistently aligns with the cultural goal stated in the Standards for Foreign language 
learning (2006), which is also adopted in the English Language Guidelines for Secondary Schools (2014) in Morocco. According to the syllabus, "learners will gain a deeper understanding of their cultures and other cultures in terms of their perspectives, practices, and products" (p.5). Using different terminology, Fantini and Fantini (1997) pointed out that for students to deepen their understanding of language and culture, they should make use of the three interrelated aspects of culture: (1) artifacts (things people make), (2) sociofacts (how people come together and for what purpose) and (3) mentifacts (what people think or believe). This three-part framework has encouraged language-culture exploration beyond observable items to the significance and social uses of those items. Tang (2006) argued that not only should students know the what and how about a culture, but also the why. It is the why that empowers and sustains the memory about a second culture accumulated in the learning process. Only when the knowledge of what is strengthened by the knowledge of why can the learner of a foreign language perform successfully in the target culture. In this study, the PjBL students were led step-by-step under the instructor's guidance to discover the what, the how, and the why about the English cultures and how they are closely interrelated. Unlike the control group, the ability to understand the interconnectedness of the three types of culture through the seven-step process could have helped the PW students gain insight into the English cultures.

The findings in this current research study are in line with the previous research findings. For example, Liu et al.'s (2006) 64 sixth graders in two American middle schools enhanced their understanding of Japanese food and culture as a result of completing their inquiry-based web projects in the form of electronic copies of travel guides. Also, Hsu's (2014) 34 college students at a national university in northern Taiwan worked in groups to research festivals within a particular foreign country or region based on their own choice. After completing their projects, the research participants reported having gained more understanding of their own and other cultures. In Vietnam, Ngo's (2014) 20 MA Englishmajored students, in a pilot study, learnt about cultural values and behaviors towards the environmental protections between cultures after having explored four micro-project topics related to the cultural values of the environment protection for 15 weeks. In the Moroccan context, Bouchouk (2017), in a recent study, asked 15 American high school students to explore aspects of Moroccan cultures based on personal interest, using PW to develop their cultural knowledge of the host country (Morocco). Bouchouk's semi-structured interview with the study participants revealed that students enriched their understanding of Moroccan cultures.

Similarly, in a very recent study, to determine whether the PjBL approach helps students develop intercultural knowledge, Kim (2019) asked 11 preservice English education students to conduct projects on four cultural topics: race and ethnicity, education, religion, and politics in Korea, the USA, and some other international cultures. Having used the sevenstep process, students completed four projects within 16 weeks. The analysis of students' weekly journals and post-project written reflections revealed that students "built deep and broad intercultural knowledge based on the four cultural topics" (p. 8). They also developed their genuine interest in the countries they explored and their connection with the cultures.

Likewise, the development of cultural understanding resulting from PW completion was also reported in some other previous research studies whose primary purpose was not culture. For example, Gu's (2002) found that Chinese students fostered their critical awareness of cultural differences and enjoyed learning from their American partners' cultural knowledge, Moreover, in the Japanese university context, some of Bulach's (2003) research participants reported that they have gained some knowledge about culture shock. In addition, they changed some of their perspectives of foreigners after having conducted their project work. Finally, while Irawati's (2015) found that students who engaged in PW on cultural issues improve their academic writing skills, they reported having enhanced their cultural understanding accordingly. 
While this study is in good agreement with those in the reviewed research studies in terms of findings, it further demonstrates how students' cultural understanding of other cultures took place through the PjBL approach (using the seven-step process). Unlike the previous research on $\mathrm{PjBL}$ in teaching cultures in language education, this study combined the cultural framework of the 3Ps and Stoller's (2012) seven-step process to teach culture through discovery learning. While all the reviewed studies used PjBL with different labels (project work, inquiry-based learning, instruction-based learning), none of them used a cultural framework to assess the level of cultural understanding gained as a result of completing culture projects. Conversely, using the 3Ps cultural framework in this study substantially contributed to students' enhancement of cultural awareness. It also served as a framework through which the degree of cultural understanding was measured. By relating cultural products and practices to perspectives, students' cultural awareness level transcends facts to include the underlying beliefs and values that justify the observable cultural aspects and behaviors.

\section{CONCLUSION}

The results of this study should be considered in light of several limitations and delimitations that could have affected the findings. Because of the research setting constraints, it was not feasible for the researcher to use a true experimental design. Although the scores on the pre-cultural awareness revealed that the two groups had been similar regarding the dependent variables, differences among members of the intact groups might have existed, which the researcher had not been conscious of, which might have influenced the results. The findings could differ if a pre- and posttest control group design with random assignment of the individuals was used. Additionally, given that the sample used was relatively small and that the study was conducted in a small school in the southeast of Morocco, the generalizability of the findings to other second-year baccalaureate levels in Moroccan high schools is decreased.

Because of the number of cultural objectives addressed in the textbooks, the selfdeveloped test could not test everything about students' knowledge of cultural products, practices, and perspectives related to the five thematic units. Therefore, the result might have been different if other cultural content had been included. Similarly, the researcher used a multiple-choice method to assess students' knowledge of products and practices and understand the underlying meaning of those products and practices. The results could differ if other test techniques were used. The present study is also limited in terms of the target cultures and cultural themes. The target cultures were restricted to the English cultures (American and British cultures), and the cultural themes are limited to those imposed by the textbooks.

While this study seems to be the first step towards enhancing our understanding of the culture teaching through the combination of the seven-step process model and the three-part framework, it has some implications for future research. First, the current experimental study was conducted in a public secondary school in the southeast of Morocco with second-year baccalaureate students. Future research could replicate this study in other Moroccan secondary schools or other similar educational contexts to confirm or disconfirm its findings. Second, although the researcher broke down the five thematic units into several sub-topics, they might have been far from motivational. Future researchers could measure the effect of $\mathrm{PjBL}$ by allowing the participants a completely free choice of their culture project topics based on their interest to investigate the correlation between the impact of the PjBL with and without a free selection of the themes on students' cultural awareness. One way to do this is to let the experimental group students choose their topics, and the same topics can be imposed on the control group students. Third, the research subjects in this study reported having considerably improved language skills after completing their cultural projects. Further inquiries could empirically investigate the effect of learning about a foreign culture through 
the seven-step process on developing students' language proficiency. Fourth, the investigator used two intact groups $(\mathrm{N}=64)$ from the same secondary school, which means that there might have been differences among group members the researcher failed to control. Although this issue was addressed through the use of a pre-cultural awareness test, it would be worthwhile for future investigations to replicate the same study in two different secondary schools using a true experimental design and larger size to validate the findings obtained here.

\section{REFERENCES}

Alan, B., \& Stoller, F. L. (2005). Maximizing the benefits of project work in foreign language classrooms. English Teaching Forum, 43(4), 10-17.

Ames, C. (1990). Motivation: What teachers need to know. Teachers College Record, 91(3), 409-421.

Ames, C. (1992). Classrooms: Goals, structures, and student motivation. Journal of Educational Psychology, 84(3), 261.

Aoki, N. (1999). Affect and the role of teachers in the development of learner autonomy. In J. Arnold (Ed.), Affect in language learning (pp. 142-154). Cambridge University Press.

Baş, G. (2011). Investigating the effects of project-based learning on students' academic achievement and attitudes towards English lesson. TOJNED: The Online Journal of New Horizons in Education, 1(4), 1-15.

Baş, G., \& Beyhan, ö. (2010). Effects of multiple intelligences supported project-based learning on students' achievement levels and attitudes towards English lesson. International Electronic Journal of Elementary Education (2)3, 366-386.

Beckett, G. H. (2002). Teacher and student evaluations of project-based instruction. TESL Canada Journal 19 (2): 52-66.

Benson, P. (2006). Autonomy in language teaching and learning. Language Teaching, 40(1), 21-40. Doi:10.1017/S0261444806003958.

Blumenfeld, P. C., Soloway, E., Marx, R. W., Krajcik, J. S., Guzdial, M. \& Palincsar, A. (1991). Motivating project-based learning: Sustaining the doing, supporting the learning. Educational Psychologist, 26 (3-4), 369-398.

Bouchouk, A. (2017). Project-based learning: Enhancing high school students' cultural knowledge and language skills. Proceedings of the 36th MATE Annual Conference. http://mate.ma/index.php/2017/12/02/proceedings-of-the-36th-annual-conference-fesmorocco-14-17-april-2016-2/

Brown, H. D. (2000). Principles of language teaching and learning. New York: Longman

Bulach, J. J. (2003). Learning English communication through project work: Reactions of Japanese university students. JALT Hokkaido Journal, 7, 44-54. https://jalthokkaido.net/pluginfile.php/51/course/section/38/Bulach.pdf

Campbell, D. T., \& Stanley, J. C. (1963). Experimental and quasi-experimental designs for research. Houghton Mifflin Company. 
Chu, S. K. W., Tse, S. K., Loh, E. K. Y., \& Chow, K. (2011). Collaborative inquiry projectbased learning: Effects on reading ability and interests. Library \& Information Science Research, 33(3), 236-243. http://web.hku.hk/ samchu/docs/Chu-2011Collaborative-IqPBL-Effects-on-Reading-Ability.pdf

Cohen, L., Manion, L., \& Morrison, K. (2000). Research methods in education 5th edition. London, Routledge

Falmer. http://dspace.utamu.ac.ug:8080/xmlui/bitstream/handle/123456789/182/ResearchMethods-in-Education-sixth-edition.pdf? sequence $=1 \&$ isAllowed $=y$

Creswell, J. W. (2012). Educational research: Planning, conducting, and evaluating quantitative and qualitative research (4th ed.). Boston, MA: Pearson.

Cutshall, S. (2012). More than a decade of standards: Integrating "cultures" in your language instruction. The Language Educator, 7(3), 32-37.

Eyring, J. L. (1997). Is project work worth it? https://eric.ed.gov

Fantini, B, C., \& Fantini, A. E. (1997). Artifacts, sociofacts and mentifacts: A sociocultural framework. In A.E. Fantini (Ed.). In A.E. Fantini (Ed.). New ways in teaching culture (pp. 57-61). Arlington, VA: TESOL.

Fetsco, T., \& McClure, J. (2005). Educational psychology: An integrated approach to classroom decisions. Allyn \& Bacon.

Fleming, D. S. (2000). A teacher's guide to project-based learning. https://eric.ed.gov

Fragoulis, I., \& Tsiplakides, I. (2009). Project-based learning in the teaching of English as a foreign language in Greek primary schools: From theory to practice. English Language Teaching, 2(3), 113-119. https://files.eric.ed.gov/fulltext/EJ1083088.pdf.

Fried-Booth, D. L. (2002). Project work. Oxford: Oxford University Press.

Gardner, D., \& Miller, L. (1999). Establishing self-access: From theory to practice. Cambridge University Press.

Gay, L. R., Mills, G. E., \& Airasian, P. W. (2012). Educational research: Competencies for analysis and applications. Merrill/Pearson.

Gu, P. (2002). Effects of project-based CALL on Chinese EFL learners. Asian journal of English language teaching, 12, 195-210.

Hall, J. K. (2013). Teaching and researching: Language and culture. Routledge.

Hammani, M., Ahssen, S. \& Tansaoui, L. (2007). Ticket to English 2. Casablanca: D.I.O. El Hadita.

Harmer, N., \& Stokes, A. (2014). The benefits and challenges of project-based learning. Plymouth University.

Hassim, M., Blibil, M. \& Rasmy, A. (2007). Gateway to English 2. Rabat: Nadia Edition.

Hedge, T. (1993). Key concepts in ELT. ELT Journal, 47(3), 275-277.

Henry, J. (1994). Teaching through projects. Routledge.

Hsu, L. Y. (2014). Integrating culture with project-based instruction in an EFL classroom. 英 語教學期刊, 38(1), 61-90. DOI: 10.6330/ETL.2014.38.1.03

Imtiaz, S., \& Asif, S. I. (2012). "I almost learnt to learn": Promoting learner's autonomy through project-based learning in Access Classrooms. Language in India, 12(1). http://www.languageinindia.com/jan2012/sanaimtiazpblfinal.pdf 
Irawati, L. (2015). Applying cultural project-based learning to develop students' academic writing. Dinamika Ilmu, 15(1), 25-33.

Jackson, S. L. (2009). Research methods and statistics: A critical thinking approach (3rd ed.). Cengage Learning.

Kim, M. K. (2019). Project-based learning experience in the construction of intercultural knowledge. Modern English Education, 20(2), 1-18. https://s3.amazonaws.com/academia.edu.

Krauss, J., \& Boss, S. (2013). Thinking through project-based learning: Guiding deeper inquiry. Corwin Press.

Lam, F. S., Wing-Yi, C. R., William, Y. K. Ma. (2009). Teacher and student intrinsic motivation in project-based learning. Instructional Science, 37 (6), 565-578.

Legutke, M., \& Thomas, H. (1991). Process and experience in the language classroom. Routledge.

Lennon, P. (2012). The story of learner autonomy: From self-access to social learning. In P. Lang (ed.), Learner autonomy in the English classroom: Empirical studies and ideas for teachers, 19-64. Peter Lang GmbH. Germany. www.uiz.Scholarvox.com

Little, D. (1999). Learner autonomy is more than a western cultural construct. In S. Cotterall \& D. Crabbe (Eds.), Learner autonomy in language learning: Defining the field and effecting change, (pp. 11-18). Peter Lang Pub Incorporated.

Liu, M., Lee, S. T., Chang, H., Trapahgan, T., \& Horton, L. (2006). Using a web enhanced, inquiry-based learning module to increase cultural awareness among middle school students. In E. Pearson \& P. Bohman (Eds.), Proceedings of World Conference on Educational Multimedia, Hypermedia and Telecommunications, 1, 1408-1415. Chesapeake, VA: AACE.

Malone, T. (1987). Making learning fun: A taxonomy of intrinsic motivations for learning. Aptitude, Learning, and Instruction, 3, 223-253.

Marczyk, G., DeMatteo, D., \& Festinger, D. (2005). Essentials of research design and methodology. John Wiley \& Sons Inc.

Migdad, I. S., (2016). The Impact of project-based learning strategy on 3rd graders' acquisition of English vocabulary and leadership skills at UNRWA schools in Gaza (Master Dissertation). https://iugspace.iugaza.edu.ps/handle/20.500.12358/18889

Mimouni, A., \& Tamer, Y. (2020). The Effect of Music on Moroccan Students' Acceptance of Kahoot Gamified Quizzing in the EFL Classroom. International Journal of Language and Literary Studies, 2(2), 210-220. https://doi.org/10.36892/ijlls.v2i2.303

Mohamadi, Z. (2018). Comparative effect of project-based learning and electronic projectbased learning on the development and sustained development of English idiom knowledge. Journal of Computing in Higher Education, 1-23. https://doi.org/10.1007/s12528-018-9169-1

Mohan, B., \& Beckett, G. H. (2003). A functional approach to research on content-based language learning: Recasts in causal explanations. The Modern Language Journal, 87(3), 421-432.

Moran, P. R. (2011). Teaching culture: Perspectives in practice. Boston, MA: Heinle \& Heinle.

Morgan, A. (1983). Theoretical aspects of project-based learning in higher education. British Journal of Educational Technology, 14 (1). pp 66-78. 
Muijs, D. (2010). Doing quantitative research in education with SPSS. Sage.

Najib, M. \& El Haddad, E. (2007). Insights into English 2. Rabat: Al Massar Edition.

Nassir, S. (2014). The effectiveness of project-based learning strategy on ninth graders' achievement level and their attitude towards English in governmental schools-north governorate (Master Dissertation). Islamic University: Gaza

Newprasit, N., \& Seepho, S. (2015). The effects of a project-based learning approach on the improvement of English language skills. Journal of Applied Language Studies and Communication (วารสาร การ ศึกษา ภาษาศาสตร์เชิง ประยุกต์ และ การ สื่อสาร), 1(1), 16-51.

Ngo, H. H. (2014). Some utilization of project-based learning for Vietnamese university students of English in the course "Intercultural Communication". International Journal of English Language Education, 2, 215-224. Doi:10.5296/ijele.v2i1.5220.

Paige, R. M., Jorstad, H., Siaya, L., Klein, F., and Colby, J. (1999) Culture learning in language education: A review of the literature. In R. M. Paige, D. L. Lange and Y. A. Yeshova (Eds.), Culture as the core: Integrating culture into the language curriculum (pp. 173-236). University of Minnesota, Minneapolis.

Pecore, J. L. (2015). From Kilpatrick's project method to project-based learning. International handbook of progressive education, 155-171. https://pdfs.semanticscholar.org/679f/6146dce2b5fb9927c21acdae176570157360.pdf.

Poupore, G. (2014). The influence of content on adult L2 learners' task motivation: An interest theory perspective. The Canadian Journal of Applied Linguistics, 17(2), 69.

Putri, N. L. P. N. S., Artini, L. P., \& Nitiasih, P. K. (2017). Project-based learning activities and EFL students' productive skills in English. Journal of Language Teaching and Research, 8(6), 1147-1155.

Reisi, M., \& Saniei, A. (2016). The contribution of word webbing to project-based learning in teaching vocabulary: A comparative study in an EFL context. Journal of Language Teaching and Research, 7(6), 1190-1197.

Richards, J. C., \& Schmidt, R. (2010). Longman dictionary of language teaching and applied linguistics (4th ed.). London: Longman Pearson Education.

Shafaei, A., \& Abdul Rahim, H. (2015). Does project-based learning enhance Iranian EFL learners' vocabulary recall and retention? Iranian Journal of Language Teaching Research, 3(2), 83-99.

Simpson, J. (2011). Integrating project-based learning in an English language tourism classroom in a Thai university (Doctoral Dissertation). Australian Catholic University, Sydney, Australia).

theses/public/adtacuvp309.29062011/02whole.pdf

Slavin R. E. (2006). Educational psychology: Theory and practice. Boston: Allyn \&Bacon.

Standards for foreign language learning in the 21st century including Arabic, Chinese, classical languages, French, German, Italian, Japanese, Portuguese, Russian, and Spanish (2006). Allen Press, Inc.

Stevenson, J. A. (1921). The project method of teaching. New York. Macmillan Company. https://scholar.google.com/scholar?hl=fr\&as_sdt=0\%2C5\&q=THE+PROJECT+METH $\mathrm{OD}+\mathrm{OF}+\mathrm{TEACHING}+\mathrm{BY}+\mathrm{JOHN}+\mathrm{ALFORD}+\mathrm{STEVENSON} \& \mathrm{btnG}=$

Stoller, F. L, (2006). Establishing a theoretical foundation for project-based learning in second and foreign language contexts. In G. H. Beckett \& P. C. Miller (Eds.), Project- 
based second and foreign language education: Past, present, and future (pp. 19-40). USA: Information Age Publishing.

Stoller, F. L. (2012). Moving students toward a perfect score with project-based learning. Keynote address at annual KOTESOL convention, Seoul, Korea.

Stoller, F. L. (2010). Promoting purposeful language learning with project work. Presentation and workshop sponsored by the Institute of English Language Education, Rikkyo University, Tokyo, Japan.

Stoller, F. L. (2014). Project-based learning: A viable option for second and foreign language classrooms. In 2012 KOTESOL Proceedings (pp. 37-47). KOTESOL.

Tang, Y. (2006). Beyond behavior: Goals of cultural learning in the second language.

Thomas, J. W. 2000. A review of research on PBL. http://www.bobpearlman.org/BestPractices/PBL_Research.pdf

Valette, R. M. (1977). The culture test. In J. M. Valdes (Ed.), Culture bound: Bridging the cultural gap in language teaching (pp. 179-197). Cambridge University Press.

Welsh, J. A. (2006). An Exploration of project-based learning in two California charter schools. (Doctoral dissertation's thesis, University of Southern California). http://digitallibrary.usc.edu/cdm/ref/collection/p15799coll16/id/426183

Woolfolk, A. (2005). Educational psychology. Pearson Education, Inc.

Yaman, I. (2014). EFL Students' attitudes towards the development of speaking skills via project-based learning: An omnipresent learning perspective (Doctoral Dissertation). https://files.eric.ed.gov/fulltext/ED577934.pdf

Yuliani, Y., \& Lengkanawati, N. S. (2017). Project-based learning in promoting learner autonomy in an EFL classroom. Indonesian Journal of Applied Linguistics, 7(2), $285-$ 293. http://ejournal.upi.edu/index.php/IJAL/article/viewFile/8131/5244

\section{$\underline{A U T H O R^{\prime} S B I O}$}

Mohamad Akharraz is an EFL instructor. He is a PhD student at Ibn Zohr University, Morocco. His areas of interest are cultural studies and applied linguistics. 